\title{
NOTES
}

\section{Synthesis of Polydimethylsiloxanes Containing Aminosilyl or Amidosilyl Groups at One Chain End}

\author{
Toshio Suzuki, ${ }^{\dagger}$ Shuji Yamada, ${ }^{*}$ and Tadashi OKawA* \\ Research Center, Dow Corning Japan Ltd., 603 Kishi, Yamakita, \\ Kanagawa 258-01, Japan \\ * Material Development Department, Dow Corning Toray Silicone Co., Ltd., \\ 2-2 Chigusa-Kaigan, Ichihara, Chiba 299-01, Japan
}

(Received September 25, 1992)

\begin{abstract}
KEY WORDS Polydimethylsiloxane / Aminosilyl / Amidosilyl / Lithium Amide / One-End Functional / Initiator Method /
\end{abstract}

Polydimethylsiloxanes (PDMS) with welldefined molecular structures prepared by non-equilibrium ring-opening polymerization of hexamethylcyclotrisiloxane $\left(\mathrm{D}_{3}\right)$ have been intensively investigated and a considerable number of reports on their syntheses, properties and applications have been published. ${ }^{1}$ We previously reported that the lithium salt of an oligosiloxanol compound containing a vinyl or hexenyl group can act as an initiator for non-equilibrium ring-opening polymerization of $\mathrm{D}_{3}$ to give a one-end alkenyl-functional PDMS. ${ }^{2}$ This method was named "initiator method" because a functional alkenyl group was present in the initiator. We also reported another example in which lithium trimethylsilylacetylide was used as the initiator to form a PDMS with a trimethylsilylethynyl group at the initiation end. ${ }^{3}$

Organosilicon compounds bearing aminosilyl or amidosilyl groups are utilized by taking advantage of their high reactivity towards active protic compounds such as water, alcohols and silanols. For example, di- or tri-functional aminosilanes are used as crosslinking agents in silicone elastomers which cure when exposed to ambient moisture. Aminosilanes, silazanes and amidosilanes can be classified as the most versatile silylating agents for alcohols, amines or silanols. ${ }^{4}$

Recently, we found that the lithium salts of diethylamine or diisopropylamine can initiate the non-equilibrium polymerization of $\mathrm{D}_{3}$ to form a PDMS containing an aminosilyl group at the initiation end. The synthetic procedure is illustrated in Scheme 1.

$$
\begin{aligned}
& \mathrm{R}_{2} \mathrm{NH}+\mathrm{BuLi} \underset{\mathrm{THF}}{\longrightarrow} \mathrm{R}_{2} \mathrm{NLi} \stackrel{\mathrm{D}_{3}}{\longrightarrow} \\
& \mathrm{R}_{2} \mathrm{~N}\left(-\mathrm{SiMe}_{2} \mathrm{O}\right)_{n} \mathrm{Li} \stackrel{\mathrm{R}^{\prime} \mathrm{Me}_{2} \mathrm{SiCl}}{\longrightarrow} \\
& \mathrm{R}_{2} \mathrm{~N}\left(-\mathrm{SiMe}_{2} \mathrm{O}\right)_{n} \mathrm{SiMe}_{2} \mathrm{R}^{\prime} \\
& \text { Scheme } 1
\end{aligned}
$$

Any functional group can be incorporated at the termination end of the PDMS as long as the corresponding chlorosilane is available.

During the course of investigating $\mathrm{Si}-\mathrm{N}$ functional PDMS, we found that PDMS containing a terminal amidosilyl group can be obtained by the reaction between PDMS with a terminal chlorosilyl group and $N$-methyl- $N$ trimethylsilylacetamide.

The first part of this report describes the synthesis of one-end aminosilyl-functional PDMS initiated by the lithium salts of 
dialkylamines, with the second part focusing on the synthesis of PDMS with terminal amidosilyl groups. It is expected that this class of PDMS will become quite versatile for the preparation of graft copolymers or star-shaped polymers as a consequence of the reactive terminal $\mathrm{Si}-\mathrm{N}$ functional groups.

\section{EXPERIMENTAL}

\section{General}

All synthetic procedures were conducted under dry argon or nitrogen atmosphere and the glassware was dried by vacuum-heating. Tetrahydrofuran (THF) was distilled from a purple solution of $\mathrm{THF} / \mathrm{Na} /$ benzophenone. Diethylamine $\left(\mathrm{Et}_{2} \mathrm{NH}\right)$ or diisopropylamine (iso $\mathrm{Pr}_{2} \mathrm{NH}$ ) was distilled and stored over activated molecular sieves. Hexamethylcyclotrisiloxane $\left(\mathrm{D}_{3}\right)$ was distilled, dissolved in dry THF $(50 \mathrm{wt} \%)$, and stored over activated molecular sieves. $N$-Methyl- $N$-trimethylsilylacetamide (TMSNMA) and the chlorosilanes were freshly distilled before use. Butyllithium (BuLi, in hexanes) was used as purchased.

\section{Measurements}

Gel permeation chromatography (GPC) was performed on a Tosoh HLC 8020 equipped with a series of Tosoh G5000HXL and GMHXL-L columns and a refractometer. Toluene was used as the eluent and standard polydimethylsiloxane samples were used for calibration. The samples were quenched with excess $\mathrm{MeOH}$ prior to GPC measurements to avoid hydrolysis/condensation reactions caused by water in the eluent. Analytical gas chromatography was carried out using a Shimadzu gas chromatograph model GLC$14 \mathrm{AH}$ equipped with a CBM1 glass capillary column. Quantitative ${ }^{1} \mathrm{H}$ and ${ }^{29} \mathrm{Si}$ NMR spectra were recorded on a Bruker AC-P 300 spectrometer $\left[300.13 \mathrm{MHz}\right.$ for ${ }^{1} \mathrm{H}$; room temperature; solvent: $\mathrm{CDCl}_{3}$; reference: $\mathrm{CHCl}_{3}$ $\left({ }^{1} \mathrm{H}\right), \mathrm{CDCl}_{3}\left({ }^{13} \mathrm{C}\right), \mathrm{Me}_{4} \mathrm{Si}\left({ }^{29} \mathrm{Si}\right)$; relaxation agent: $\left.\mathrm{Cr}(\mathrm{acac})_{3}(0.02 \mathrm{M})\right]$. Gas chromatog- raphy-mass spectrometric (GC-MS) data were obtained using a Shimadzu GCMS-QP1000EX gas chromatograph-mass spectrometer.

\section{1-Diethylamino-7-vinyloctamethyltetrasiloxane}

To a solution of $\mathrm{Et}_{2} \mathrm{NH}(18.8 \mathrm{~g}, 0.26 \mathrm{~mol})$ in THF $(50 \mathrm{ml})$ at $-78^{\circ} \mathrm{C}$ was added $\mathrm{BuLi}$ $(0.25 \mathrm{~mol})$ over a period of $30 \mathrm{~min}$. The mixture was allowed to warm to room temperature, mixed for further $30 \mathrm{~min}$, and then cooled again with an ice bath. $\mathrm{D}_{3}$ in THF $(55 \mathrm{~g}, 0.25 \mathrm{~mol})$ was added to the mixture and stirred for $30 \mathrm{~min}$ at $0^{\circ} \mathrm{C}$. Chlorodimethylvinylsilane $(35 \mathrm{~g}, 0.29$ mol) was then added to the mixture while maintaining a temperature at $0^{\circ} \mathrm{C}$. A white precipitate appeared about $30 \mathrm{~s}$ later, which was then removed by filtration. After evaporation of the solvent and unreacted materials under vacuum at room temperature, 1 was collected by fractional distillation. Yield $43 \%$. bp $108^{\circ} \mathrm{C} / 6 \mathrm{mmHg}$. Purity by GC: $>99 \%$. ${ }^{1} \mathrm{H}$ $\operatorname{NMR}(\delta, \mathrm{ppm}): 6.18-5.68(\mathrm{~m}, 3 \mathrm{H}), 2.82(\mathrm{q}$, $4 \mathrm{H}), 0.98(\mathrm{t}, 6 \mathrm{H}), 0.14(\mathrm{~s}, 6 \mathrm{H}), 0.06(\mathrm{~s}, 6 \mathrm{H})$, $0.04(\mathrm{~s}, 6 \mathrm{H}), 0.03(\mathrm{~s}, 6 \mathrm{H}) .{ }^{29} \mathrm{Si} \mathrm{NMR}(\delta, \mathrm{ppm})$ : -4.20 ( $\left.\mathrm{ViMe}_{2} \mathrm{SiO}-\right),-12.15\left(\mathrm{Et}_{2} \mathrm{NMe}_{2} \mathrm{SiO}-\right)$, $-21.21\left(\mathrm{ViMe}_{2} \mathrm{SiOMe}_{2} \mathrm{SiO}-\right),-23.22\left(\mathrm{Et}_{2} \mathrm{~N}-\right.$ $\mathrm{Me}_{2} \mathrm{SiOMe}_{2}$ SiO-). ${ }^{13} \mathrm{C} \mathrm{NMR}(\delta, \mathrm{ppm}): 139.18$, $131.37,39.30,15.61,0.95,0.89,0.05,-0.50$. GC-MS m/z (relative abundance): $379\left(\mathrm{M}^{+}\right.$, 3), $364\left(\mathrm{M}^{+}-\mathrm{Me}, 60\right), 307$ (27), 219 (54), 207 (100), 130 (30), 85 (37), 73 (75).

1-Diethylaminononamethyltetrasiloxane (2) was prepared in a similar way. Yield $31 \%$. bp $60^{\circ} \mathrm{C} / 0.1 \mathrm{mmHg}$. Purity by GC: $>98 \% .{ }^{1} \mathrm{H}$ $\operatorname{NMR}(\delta, \mathrm{ppm}): 2.82(\mathrm{q}, 4 \mathrm{H}), 0.98(\mathrm{t}, 6 \mathrm{H}), 0.08$ $(\mathrm{s}, 9 \mathrm{H}), 0.07(\mathrm{~s}, 6 \mathrm{H}), 0.04(\mathrm{~s}, 6 \mathrm{H}), 0.03(\mathrm{~s}, 6 \mathrm{H})$. ${ }^{29} \mathrm{Si} \mathrm{NMR}(\delta, \mathrm{ppm}): 7.03\left(\mathrm{Me}_{3} \mathrm{SiO}-\right),-12.26$ $\left(\mathrm{Et}_{2} \mathrm{NMe}_{2} \mathrm{SiO}_{-}\right),-21.80\left(\mathrm{Me}_{3} \mathrm{SiOMe}_{2} \mathrm{SiO}-\right)$, $-23.38\left(\mathrm{Et}_{2} \mathrm{NMe}_{2} \mathrm{SiOMe}_{2} \mathrm{SiO}-\right) .{ }^{13} \mathrm{C} \mathrm{NMR}$ $(\delta, \mathrm{ppm}): 39.43,15.73,1.68,1.04,-0.39$. GC-MS $m / z$ (relative abundance): $367\left(\mathrm{M}^{+}, 3\right)$, $352\left(\mathrm{M}^{+}-\mathrm{Me}, 40\right), 295$ (26), 207 (100), 130 (39), 73 (50). 
Polymerization Initiated by $\mathrm{LiNEt}_{2}$ (4 in Table

1)

To a solution of $\mathrm{Et}_{2} \mathrm{NH}(0.90 \mathrm{~g}, 12 \mathrm{mmol})$ in THF $(10 \mathrm{ml})$ cooled to $0^{\circ} \mathrm{C}$ was added $\mathrm{BuLi}$ $(12 \mathrm{mmol})$ over a period of $2 \mathrm{~min}$. After stirring at $0^{\circ} \mathrm{C}$ for $30 \mathrm{~min}, \mathrm{D}_{3}$ in THF $(50 \mathrm{~g}, 225 \mathrm{mmol})$ was added to the solution in one portion. The reaction mixture was allowed to warm to room temperature and the consumption of $\mathrm{D}_{3}$ was monitored by GC. When the consumption reached $83 \%$, chlorodimethylsilane $(2.7 \mathrm{~g}$, $28 \mathrm{mmol}$ ) was added to the solution. The solvents and unreacted materials were removed by vacuum evaporation (up to $100^{\circ} \mathrm{C}$ ) and $\mathrm{LiCl}$ was removed by filtration to give $36.7 \mathrm{~g}$ of polymer. Yield (based on BuLi): $85 \% .{ }^{1} \mathrm{H}$ NMR ( $\delta, \mathrm{ppm}): 4.70(\mathrm{~m}), 2.82(\mathrm{q}), 0.98(\mathrm{t}), 0.07$ (s). ${ }^{29} \mathrm{Si}$ NMR $(\delta, \mathrm{ppm}):-6.89,-12.11$, $-19.85,-21.89,-23.13$.

Other polymerizations initiated by lithium diethylamide or lithium diisopropylamide were carried out in a similar manner. NMR data for 3: ${ }^{1} \mathrm{H}$ NMR $(\delta, \mathrm{ppm}): 6.18-5.68(\mathrm{~m}), 2.82(\mathrm{q})$, $0.98(\mathrm{t}), 0.07(\mathrm{~s}) .{ }^{29} \mathrm{Si}$ NMR $(\delta \mathrm{ppm}):-4.20$, $-12.22,-21.03,-22.05,-23.27$. NMR data for 5: ${ }^{1} \mathrm{H}$ NMR $(\delta, \mathrm{ppm}): 4.70(\mathrm{~m}), 3.20$ (sept), 1.07 (d), $0.06(\mathrm{~s}) .{ }^{29} \mathrm{Si} \mathrm{NMR}(\delta, \mathrm{ppm}):-6.92$, $-13.84,-19.89,-21.94,-23.67$.

\section{1-(N-Methylacetamido)-7-vinyloctamethylte- trasiloxane (6)}

To a flask containing 1-chloro-7-vinyloctamethyltetrasiloxane ${ }^{5} \quad(4.2 \mathrm{~g}, 12 \mathrm{mmol})$, TMSNMA $(2.2 \mathrm{~g}, 15 \mathrm{mmol})$ was added with stirring at room temperature. The mixture was stirred for $30 \mathrm{~min}$, during which time a slight exotherm was observed. A vacuum was then applied to the mixture to remove $\mathrm{Me}_{3} \mathrm{SiCl}$ and unreacted TMSNMA. Hydrolysis of the product and subsequent $\mathrm{pH}$ measurement indicated that only a trace amount of the $\mathrm{Si}-\mathrm{Cl}$ species was remaining. Yield: $98 \%$. ${ }^{1} \mathrm{H}$ NMR ( $\delta, \mathrm{ppm}): 6.10-5.61(\mathrm{~m}, 3 \mathrm{H}), 2.74(\mathrm{~s}, 3 \mathrm{H}), 1.98$ (s, 3H), $0.24(\mathrm{~s}, 6 \mathrm{H}), 0.08(\mathrm{~s}, 6 \mathrm{H}), 0.02(\mathrm{~s}, 6 \mathrm{H})$, $-0.01(\mathrm{~s}, 6 \mathrm{H}),{ }^{29} \mathrm{Si} \mathrm{NMR}(\delta, \mathrm{ppm}):-3.83$ $\left(\mathrm{ViMe}_{2} \mathrm{SiO}_{-}\right),-7.22$ (AcMeNMe $\left.{ }_{2} \mathrm{SiO}_{-}\right)$,
$-20.84\left(-\mathrm{Me}_{2} \underline{\mathrm{SiO}}-\right)$.

\section{Amidosilyl-Functional PDMS}

To a flask containing $\mathrm{D}_{3}(52 \mathrm{~g}, 230 \mathrm{mmol})$ and THF $(65 \mathrm{ml}), \mathrm{BuLi}(22 \mathrm{mmol})$ was added in one portion with stirring at room temperature. When the consumption of $\mathrm{D}_{3}$ reached $85 \%$, the mixture was transferred to a separate flask containing dichlorodimethylsilane $(12.9 \mathrm{~g}$, $100 \mathrm{mmol})$ and THF $(20 \mathrm{ml})$. The transfer was made over a period of $5 \mathrm{~min}$ with constant stirring. The solvents and unreacted materials were removed under vacuum at $80^{\circ} \mathrm{C}$ and $\mathrm{LiCl}$ was removed by filtration. The resulting polymer $(38 \mathrm{~g})$ had an $M_{n}$ of 2000 and $M_{w}$ of 2500 according to a GPC measurement (after quenching with excess $\mathrm{MeOH}$ ). Thus, it was assumed that this polymer has the structure $\mathrm{Bu}\left(\mathrm{SiMe}_{2} \mathrm{O}\right)_{27} \mathrm{SiMe}_{2} \mathrm{Cl}\left[{ }^{29} \mathrm{Si} \mathrm{NMR}(\delta, \mathrm{ppm})\right.$ : $7.63,3.58,-19.08,-21.34,-21.90,-22.52]$. A flask was charged with this polymer $(30 \mathrm{~g}$, $15 \mathrm{mmol})$ and TMSNMA $(4.6 \mathrm{~g}, 32 \mathrm{mmol})$ and heated to $50^{\circ} \mathrm{C}$ with stirring. After stirring for $4 \mathrm{~h}, \mathrm{Me}_{3} \mathrm{SiCl}$ and unreacted TMSNMA were removed by vacuum evaporation to give PDMS 7 (30 g, 99\%). ${ }^{1} \mathrm{H}$ NMR $(\delta, \mathrm{ppm}): 2.82$ $(\mathrm{s}), 2.06(\mathrm{~s}), 1.32(\mathrm{~m}), 0.89(\mathrm{t}), 0.57(\mathrm{t}), 0.32(\mathrm{~s})$, 0.09 (s). ${ }^{29} \mathrm{Si} \mathrm{NMR}(\delta, \mathrm{ppm}): 7.63,-7.22$, $-20.91,-21.90,-22.52$.

\section{RESULTS AND DISCUSSION}

\section{Aminosilyl-Functional PDMS \\ Model Compound}

1-Diethylamino-7-vinyloctamethyltetrasiloxane. $\mathrm{Et}_{2} \mathrm{~N}\left(\mathrm{SiMe}_{2} \mathrm{O}\right)_{3} \mathrm{SiMe}_{2} \mathrm{Vi}(\mathbf{1})$ was used as a model compound for the analogous higher polymers. ${ }^{1} \mathrm{H}$ and ${ }^{13} \mathrm{C}$ NMR as well as GC-MS spectral data support the expected structure 1 (see EXPERIMENTAL section). Due to the lack of chemical shift data in ${ }^{29} \mathrm{Si}$ NMR analysis for this particular class of polymers, each of the four signals had to be assigned based on shift differences before and after methoxylation of the sample. The assignments thus made are shown in the experimental section. The 
Table I. Aminosilyl-functional PDMS

\begin{tabular}{|c|c|c|c|c|c|c|c|c|}
\hline \multirow{2}{*}{ No. } & \multirow{2}{*}{$\mathbf{R}^{\mathrm{a}}$} & \multirow{2}{*}{$\mathbf{R}^{\prime \mathbf{a}}$} & \multicolumn{2}{|c|}{ Theoretical $^{\mathbf{b}}$} & \multicolumn{2}{|c|}{ GPC } & \multicolumn{2}{|c|}{$n$ by NMR } \\
\hline & & & $n$ & $M$ & $M_{n}$ & $M_{w}$ & ${ }^{1} \mathrm{H}$ & ${ }^{29} \mathrm{Si}$ \\
\hline 3 & $\mathrm{Et}$ & $\mathrm{Vi}$ & 32 & 2510 & 2680 & 3230 & 37 & 33 \\
\hline 4 & Et & $\mathrm{H}$ & 47 & 3620 & 4220 & 5170 & 44 & 47 \\
\hline 5 & isoPr & $\mathrm{H}$ & 22 & 1790 & 2000 & 2830 & 19 & 23 \\
\hline
\end{tabular}

a See Scheme 1 .

b Calculated from the amounts of BuLi and consumed $D_{3}$.

formation of $\mathrm{MeO}\left(\mathrm{SiMe}_{2} \mathrm{O}\right)_{3} \mathrm{SiMe}_{2} \mathrm{Vi}$ upon the addition of methanol was confirmed by GC-MS.

The conversion of the amine into the corresponding lithium amide can be regarded as quantitative because no formation of siloxane species with a butylsilyl group was observed, i.e., no unreacted BuLi remained when $\mathrm{D}_{3}$ was added to the reaction mixture.

Polymer Synthesis. Three kinds of aminosilyl-functional PDMS were prepared. Their molecular weights and degrees of polymerization as determined by GPC and NMR are listed in Table I.

Each of the polymers showed a narrow molecular weight distribution, typical of the non-equilibrium polymerization of $\mathrm{D}_{3}$. The molecular weights relative to standard PDMS samples are in good agreement with the theoretical values as calculated from the amounts of consumed $\mathrm{D}_{3}$ and loaded $\mathrm{BuLi}$. The NMR data of the polymers are consistent with the expected structures based on comparision with those of 1 . Figure 1 shows the ${ }^{29} \mathrm{Si}$ NMR spectrum of $\mathbf{3}$ as a typical example.

When 3 (without solvent) was exposed to ambient moisture for $24 \mathrm{~h}$, its $M_{n}$ as determined by GPC increased from 2680 to 4470 and the molecular weight distribution did not change significantly (from 1.20 to 1.25 ). This indicates that 3 underwent hydrolysis to form a silanol species which subsequently condensed with the available aminosilyl groups (Scheme 2). Since terminal silanol groups attached to a polymeric siloxane species are very stable towards self- condensation at room temperature, ${ }^{6}$ the increase in molecular weight strongly suggests the occurrence of condensation between aminosilyl groups and silanol groups. The fact that the $M_{n}$ after hydrolysis (4470) is less than double to the original value (2680) implies that there were residual terminal silanol groups. The well-retained molecular weight distribution can be regarded as evidence that each polymer molecule of $\mathbf{3}$ had exactly one aminosilyl group at the initiation end.

$$
\begin{aligned}
& \mathrm{Et}_{2} \mathrm{~N}-\left(\mathrm{SiMe}_{2} \mathrm{O}\right)_{n}-\mathrm{SiMe}_{2} \mathrm{Vi} \underset{-\mathrm{Et}_{2} \mathrm{NH}}{\stackrel{\mathrm{H}_{2} \mathrm{O}}{\longrightarrow}} \\
& \mathrm{HO}+\left(\mathrm{SiMe}_{2} \mathrm{O}\right)_{n} \mathrm{SiMe}_{2} \mathrm{Vi} \underset{-\mathrm{Et}_{2} \mathrm{NH}}{\stackrel{3}{\longrightarrow}} \\
& \mathrm{Vi}-\left(-\mathrm{SiMe}_{2} \mathrm{O}\right)_{2 n+1} \mathrm{SiMe}_{2} \mathrm{Vi}
\end{aligned}
$$

\section{Amidosilyl-Functional PDMS}

Model Compound. Since the starting chlorotetrasiloxane had an unambiguous structure and the transsilylation reaction is known to be straightforward, it is quite reasonable to assume that the product has structure 6. The assignments for the ${ }^{29} \mathrm{Si} \mathrm{NMR}$ signals had to be made using methoxylation due to the lack of literature data. The assignments are listed in the EXPERIMENTAL section. It was not possible to obtain satisfactory GC/MS data for this compound, probably because of its high reactivity with the coating material of the GC column.

Polymer Synthesis. PDMS containing a 
One-End Si-N Functional PDMS

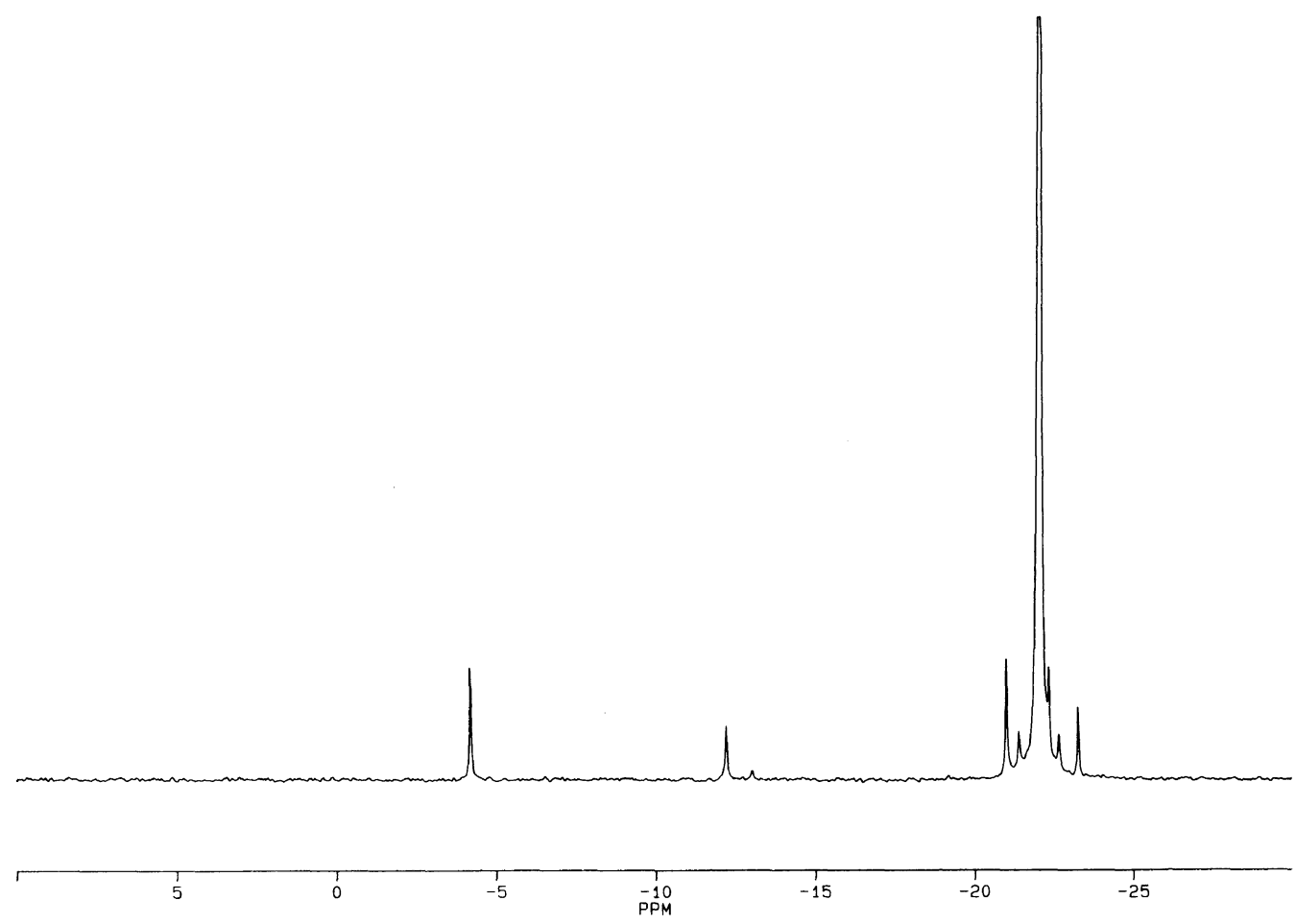

Figure 1. ${ }^{9} \mathrm{Si}$ NMR spectrum of amino-functional PDMS 3.

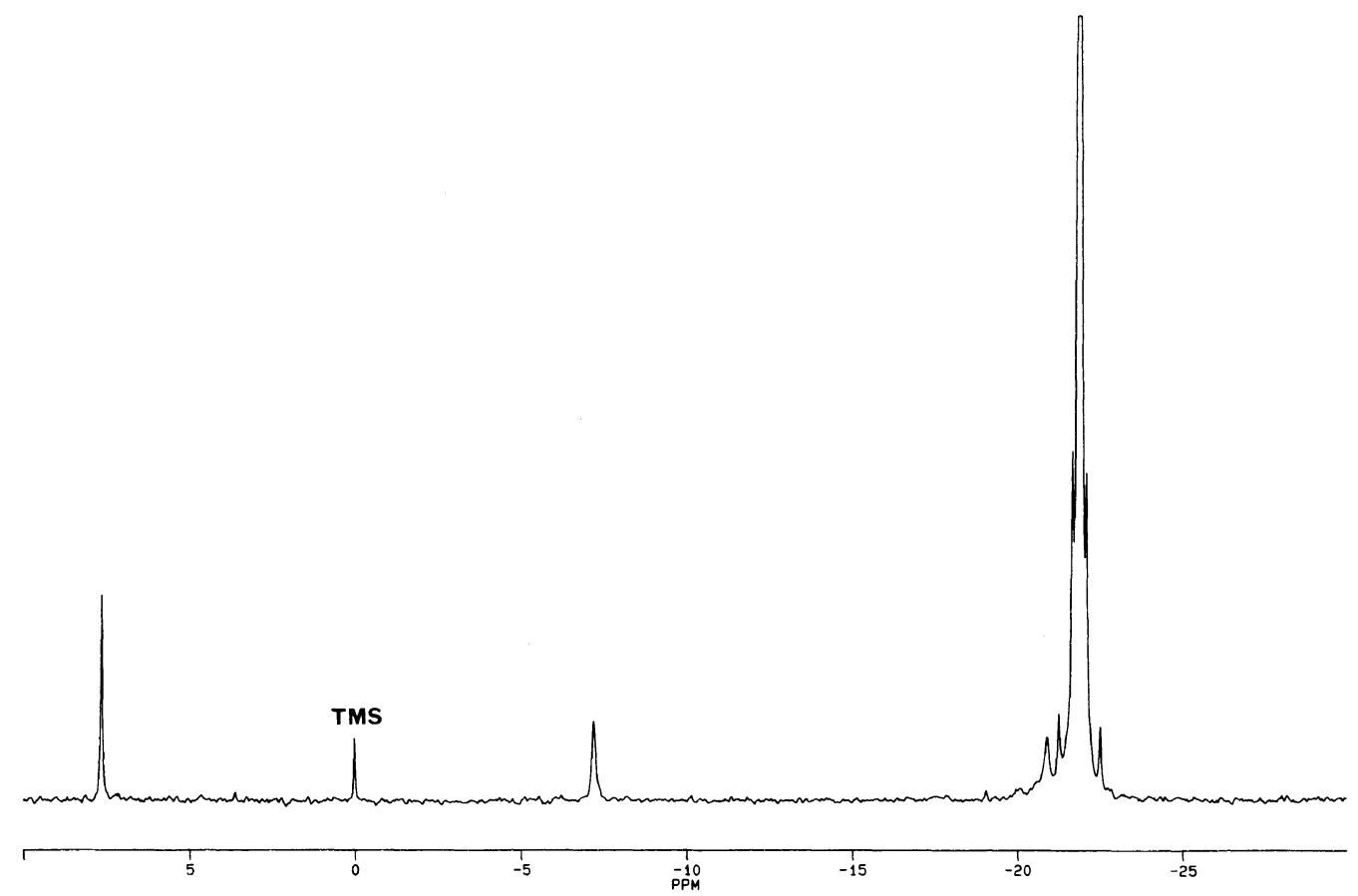

Figure 2. ${ }^{29} \mathrm{Si}$ NMR spectrum of amido-functional PDMS 7. 
chlorosilyl group at one end and a butylsilyl group at the other was prepared from $\mathrm{BuLi}$, $\mathrm{D}_{3}$, and dichlorodimethylsilane using the usual non-equilibrium polymerization technique. The chloro-functional polymer thus obtained underwent transsilylation with $\mathrm{N}$-methyl- $\mathrm{N}$ trimethylsilylacetamide to give the desired amido-functional PDMS (7) as illustrated in Scheme 3.

$$
\begin{aligned}
& \mathrm{BuLi} \stackrel{\mathrm{D}_{3}}{\longrightarrow} \frac{\text { excess } \mathrm{Me}_{2} \mathrm{SiCl}_{2}}{-\mathrm{LiCl}} \\
& \mathrm{Bu}\left(-\mathrm{SiMe}_{2} \mathrm{O}\right)_{n}-\mathrm{SiMe}_{2} \mathrm{Cl} \frac{\mathrm{Me}_{3} \mathrm{SiN}(\mathrm{Me}) \mathrm{Ac}}{-\mathrm{Me}_{3} \mathrm{SiCl}} \\
& \mathrm{Bu}\left(-\mathrm{SiMe}_{2} \mathrm{O}\right)_{n}-\mathrm{SiMe}_{2}-\mathrm{N} \\
& 7
\end{aligned}
$$

Scheme 3

The polymer, according to GPC analysis after methoxylation, had a $M_{n}$ of 2120 and $M_{w}$ of 2610 . The former is very close to the theoretical value of $2150 .{ }^{29} \mathrm{Si}$ and ${ }^{1} \mathrm{H}$ NMR spectroscopic data are consistent with those of the model compound. The ${ }^{29} \mathrm{Si}$ NMR spectrum is shown in Figure 3.

When 7 was exposed to the ambient moisture for $24 \mathrm{~h}$, its $M_{n}$ as determined by GPC increased from 2120 to 4150 . The GPC traces before and after the exposure to moisture are presented in Figure 3. As in the case of the amino-functional PDMS, the molecular weight distribution did not change significantly, indicating that 7 had

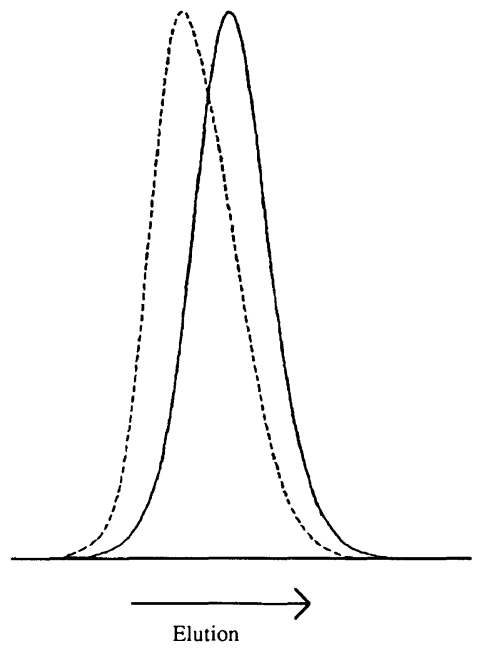

Figure 3. GPC traces of 7: Solid line, before hydrolysis; Dotted line, after hydrolysis (ambient moisture, $24 \mathrm{~h}$ ).

a well defined molecular structure.

\section{REFERENCES}

1. For review: I. Yilgor and J. E. McGrath, $A d v$. Polym. Sci., 29, 1 (1989).

2. T. Suzuki and T. Okawa, Polym. Commun., 29, 225 (1988).

3. T. Suzuki and P. Y. Lo, Macromolecules, 24, 460 (1991).

4. F. O. Stark, J. R. Falender, and A. P. Wright, in "Silicones," G. Wilkinson, F. G. A. Stone, and E. W. Abel, Ed., "Comprehensive Organometallic Chemistry," Pergamon Press, Oxford, 1982, p 319.

5. T. Suzuki, Polymer, 30, 333 (1989).

6. F. O. Stark, J. R. Falender, and A. P. Wright, in "Silicones," G. Wilkinson, F. G. A. Stone, and E. W. Abel, Ed., "Comprehensive Organometallic Chemistry,” Pergamon Press, Oxford, 1982, p 328. 